\title{
Influence of Thrombus Composition on Thrombectomy: ADAPT vs. Balloon Guide Catheter and Stent Retriever in a Flow Model
}

\section{Einfluss der Thrombus-Zusammensetzung auf die Thrombektomie: ADAPT gegen Balloon-Guide-Catheter und Stent-Retriever in einem Flussmodell}

\author{
Authors \\ Jawid Madjidyar, Lorena Pineda Vidal, Naomi Larsen, Olav Jansen
}

Affiliation

Radiology and Neuroradiology, University Hospital

Schleswig-Holstein, Kiel, Germany

Key words

interventional procedures, ischemia/infarction, stent retriever, ADAPT, balloon guide catheter

received 15.05.2019

accepted 01.08.2019

Bibliography

DOI https://doi.org/10.1055/a-0998-4246

Published online: 12.9.2019

Fortschr Röntgenstr 2020; 192: 257-263

(C) Georg Thieme Verlag KG, Stuttgart · New York

ISSN 1438-9029

Correspondence

Jawid Madjidyar

Department of Radiology and Neuroradiology, University

Hospital Schleswig-Holstein, Arnold-Heller-Str. 3, 24105 Kiel,

Germany

Tel.: ++ 49/431/5974806

Fax: ++ $49431 / 5974913$

jawid.madjidyar@uksh.de

\section{ZUSAMMENFASSUNG}

Zielsetzung Alleinige direkte Aspiration und Stent-Retriever mit Ballon-Führungskathetern stellen erweiterte Thrombektomie-Techniken dar, die ihren festen Bestand in der klinischen Routine haben. In dieser experimentellen Studie sollte untersucht werden, ob die Effektivität dieser Techniken von der Thrombus-Komposition abhängig ist und wie die Interaktion der Thromben mit den einzelnen Devices ist.

Material und Methoden Erythrozyten-reiche (rot) Thromben und Fibrinthromben (weiß) aus humanem Blut sind in das M1Segment der A. cerebri media eines transparenten Silikonmodels des vorderen Kreislaufs mit physiologischer Architektur platziert worden. Mittels einer programmierbaren Pumpe wurden physiologische hämodynamische Bedingungen erreicht. Die Thrombektomie erfolgte entweder durch direkte, alleinige Aspiration mittels einem 5F-Aspirationskatheter oder mit einem Stent-Retriever und Ballon-Führungskatheter (Flussarrest/-umkehr). Die Experimente wurden unter Sicht durchgeführt, um die Interaktion zwischen den Thromben und den Devices nachvollziehen zu können. Primäre Endpunkte waren die Anzahl benötigter Thrombektomie-Manöver und das Auftreten von distalen Embolien oder Embolien in neuen Territorien (A. cerebri anterior) bis zur vollständigen Rekanalisation. Die Experimente wurden mit einer Full-HD-Kamera dokumentiert, anhand der Videos wurde das Auftreten von Embolien beurteilt.

Ergebnisse Pro Thrombus-Art und Thrombektomie-Technik sind jeweils 6 Versuche durchgeführt worden. Rote Thromben konnten mittels alleiniger Aspiration vor Ort geborgen werden, wobei weniger Manöver nötig waren und weniger distale Embolien entstanden. Die weißen Thromben haben die Spitze des Aspirationskatheters in allen Fällen vollständig verstopft, sodass die Thromben ungeschützt bis in die lange Schleuse in der zervikalen A. carotis interna zurückgezogen werden mussten. Weiße Thromben konnten mittels Stent-Retriever und Ballon-Führungskatheter mit distalen Embolien geborgen werden; die Anzahl der Manöver war gleich. Bei beiden ThrombusArten war die Interaktion zwischen Stent-Retriever und Thrombus oberflächlich, sodass die Thromben entlang des Stents nach distal rollten. Die erfolgreiche Thrombektomie war vor allem durch den Flussarrest und die Flussumkehr möglich. Embolien in die A.cerebri anterior sind jeweils in 1 Fall mit beiden Techniken bei weißen Thromben aufgetreten.

Schlussfolgerung Diese experimentelle Studie zeigt, dass die Effektivität der Thrombektomie-Technik von der ThrombusKomposition abhängen könnte. Die Identifizierung der richtigen Technik für einen bestimmten Thrombus könnte die Rekanalisationsergebnisse optimieren. Im klinischen Kontext könnte die Morphologie des Thrombus in der dünnschichtigen nativen $\mathrm{CT}$ einen Marker für die Auswahl der Technik darstellen.

\section{Kernaussagen:}

- Die Effektivität der Thrombektomie-Technik scheint von der Thrombus-Komposition abzuhängen.

- Die alleinige Aspiration scheint effektiver für rote Thromben zu sein.

- Stent-Retriever und Ballon-Führungskatheter scheinen effektiver für weiße Thromben zu sein. 


\section{ABSTRACT}

Purpose A first-pass, direct aspiration technique and stent retrieval with a balloon guide catheter represent advanced thrombectomy techniques that are increasingly being used in the clinical routine. The purpose of this experimental study was to evaluate whether the techniques' effectiveness depended on the clot composition and to visualize the interaction between the devices and the clot.

Materials and Methods Erythrocyte-rich (red) and fibrin-rich (white) clots were placed into the M1-segment of the middle cerebral artery in a transparent vascular phantom with physiological architecture. Physiological hemodynamic conditions were maintained with a programmable pump. On the one hand direct aspiration with a $5 \mathrm{~F}$ aspiration catheter (ADAPT) and on the other hand stent retrieval with a balloon guide catheter (flow arrest/reversal) was performed. The experiments were made under direct visual control to observe the interaction between the devices and the clot. The primary end points were the number of passes/maneuvers and the occurrence of distal emboli and emboli in a new territory (anterior cerebral artery), until full recanalization was achieved. The experiment was filmed with a full high-definition camera identifying emboli.

Results Six experiments were conducted for each technique and clot model. Red clots were retrieved by ADAPT with fewer passes and distal emboli, and could usually be aspirated directly at the occlusion site. White clots clogged the tip of the $5 \mathrm{~F}$ aspiration catheter in every experiment. The catheter had to be pulled back into the long sheath in the cervical internal carotid artery, producing distal emboli. White clots were retrieved by the stent retriever and balloon guide catheter with fewer distal emboli. There was no difference in the number of passes. The stent-thrombus interaction was superficial in both clot models. Successful retrieval was granted by the flow arrest and proximal aspiration/flow reversal. One embolus in a new territory developed when using each technique in white clots.

Conclusion This experimental study showed that the efficacy of advanced thrombectomy techniques might depend on clot composition. Identifying the right technique for the right clot might improve the results of thrombectomy. In a clinical setting the thrombus morphology in non-enhanced CT could be used as a marker for patient selection.

\section{Key Points:}

- The efficacy of thrombectomy seems to depend on thrombus composition.

- ADAPT might be more effective for rbc-rich clots.

- Thrombectomy with BGC might be more effective for fibrin-rich clots.

\section{Citation Format}

- Madjidyar J, Pineda Vidal L, Larsen N et al. Influence of Thrombus Composition on Thrombectomy: ADAPT vs. Balloon Guide Catheter and Stent Retriever in a Flow Model. Fortschr Röntgenstr 2020; 192: 257-263

\section{Purpose}

In ischemic stroke caused by large-vessel occlusion, mechanical thrombectomy with stent retrievers (SR) is the standard therapy, in addition to systemic lysis [1-5]. The different SRs seem to perform equally well [6-9]. Additional aspiration is thought to improve the effectiveness of thrombectomy $[6,9,10]$. Aspiration can be performed distally using an intermediate catheter or proximally using a balloon guide catheter (BGC). Moreover, new intermediate catheters (i. e., SOFIA (Microvention, USA), ACE (Penumbra, USA)) have shown promising results in a direct aspiration, first-pass technique (ADAPT) [11, 12]. The ASTER trial showed that ADAPT was not superior to stent thrombectomy. The clinical results did not show any significant differences [13].

Experimental studies on ADAPT and BGC under standardized conditions with a transparent flow model may help to provide more objective results, while a special focus should be placed on the influence of the clot composition and the interaction between the vessel and the devices during each thrombectomy maneuver.

\section{Materials and Methods}

\section{Thrombus models}

Two different clot models were used for the experimental studies [14-16]:

1. An erythrocyte-rich (red) clot: fresh human blood was put in a Chandler loop system to create a thrombus under dynamic conditions. The clots were cut into pieces $10 \times 3.5 \mathrm{~mm}$ in size.

2. A fibrin-rich (white) clot: citrated human blood was stored standing for $24 \mathrm{~h}$. The plasma, the buffy coat, and a few erythrocytes were aspirated. The sample was recalcified and incubated for a further $72 \mathrm{~h}$. The clots were cut into pieces $10 \times 3.5 \mathrm{~mm}$ in size.

\section{Flow model}

The experiments were performed under standardized and physiological hemodynamic conditions. The flow model consists of a custom-made, transparent silicon phantom (Elastrat, Switzerland) of the right anterior circulation (common carotid artery, internal carotid artery, external carotid artery, middle cerebral artery, and anterior cerebral artery), which has a physiological curvature and inner diameters, including the proximal M2 and A2 segments. To decrease friction, the inside of the phantom was coated with Slippery-Liquid (Elastrat Sarl, Switzerland) before each use. Glycerol-saline solution was used to mimic blood (60/40 by 

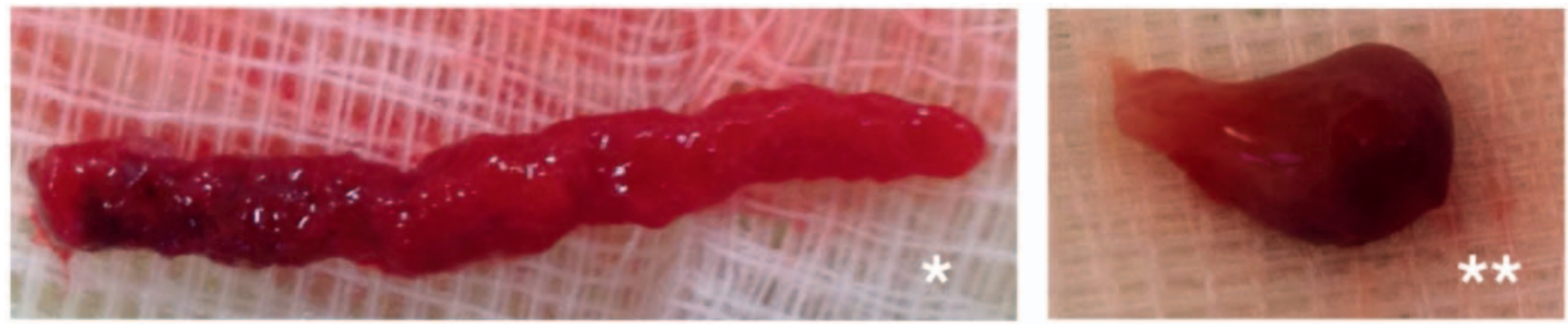

- Fig. 1 Thrombus models: $\left({ }^{*}\right)$ Erythrocyte-rich (red) thrombus; $\left({ }^{* *}\right)$ fibrin-rich (white) thrombus.

- Abb. 1 Thrombus-Modelle: $\left({ }^{*}\right)$ Erythrozyten-reicher (roter) Thrombus, $\left({ }^{* *}\right)$ Fibrin-reicher (weißer) Thrombus.

- Table 1 Summary of the results.

- Tab. 1 Zusammenfassung der Ergebnisse.

\begin{tabular}{|c|c|c|c|c|c|}
\hline clot model & technique & $\begin{array}{l}\text { median and interquartile } \\
\text { range number of passes }\end{array}$ & rate of distal emboli & $\begin{array}{l}\text { total number of } \\
\text { distal emboli }\end{array}$ & $\begin{array}{l}\text { rate of embolism in } \\
\text { new territories }\end{array}$ \\
\hline \multirow[t]{2}{*}{ red (erythrocyte-rich) } & $\mathrm{BGC}+\mathrm{SR}$ & $1(1-1.75)$ & $4 / 6$ & 5 & $1 / 6$ \\
\hline & ADAPT & $1.5(1-2)$ & $2 / 6$ & 2 & $1 / 6$ \\
\hline \multirow[t]{2}{*}{ white (fibrin-rich) } & $\mathrm{BGC}+\mathrm{SR}$ & $1(1-1)$ & $1 / 6$ & 1 & $0 / 6$ \\
\hline & ADAPT & $1(1-1)$ & $3 / 6$ & 6 & $0 / 6$ \\
\hline
\end{tabular}

volume saline/glycerin; $37^{\circ} \mathrm{C}$ ). A precise, programmable piston pump (CompuFlow 1000, Shelley Medical Imaging Technologies, Canada) produced a physiological flow velocity and flow profile, which was monitored by Doppler sonography (carotid profile, velocity of $100 \mathrm{~cm} / \mathrm{s}$, pulse $60 / \mathrm{min}$ ). Interposed resistances guaranteed physiological pressure, which was monitored invasively (middle pressure $100 \mathrm{mmHg}$ ). The clots were injected into the model and flowed into the M1 segment of the MCA. All thrombectomy procedures were recorded on video (Full High Definition, 60 frames per second, Panasonic HC-V250, Japan). Simultaneously, the video signal was broadcast live to a monitor simulating an angio-suite-like setup.

\section{Advanced Thrombectomy Techniques}

The following recanalization techniques were used:

1. ADAPT: An intermediate aspiration catheter (SOFIA 5F, Microvention, USA) was placed directly proximal to the occlusion site and continuous machine aspiration was performed (Penumbra Aspiration Pump, USA). If the tip was blocked by the clot, the intermediate catheter was pulled back into the long sheath (Arrow-Flex 6F, $90 \mathrm{~cm}$, Teleflex, Ireland) in the ICA. While withdrawing the distal catheter, we performed an additional aspiration via the sheath using a 20-ml Luer-Lock syringe. If necessary, subsequent passes followed.

2. An SR with proximal flow arrest and aspiration (SR+BGC): A SR $(4 \times 20 \mathrm{~mm}$ Trevo ProVue, Stryker, USA) was placed at the occlusion site over a microcatheter (Trevo 0.021, Stryker, USA) such that the clot was in the proximal part of the working zone. A BGC (Cello 7F, Covidien, USA) was placed in the subpetrous part of the ICA. Just before retrieving the clot, the balloon of the BGC was inflated, creating complete proximal flow arrest. Proximal machine aspiration was performed simultaneously (Penumbra Aspiration Pump, USA) when the SR was retracted into the BGC. After the SR was pulled out of the BGC, the balloon was deflated. If necessary, subsequent passes followed.

\section{Analysis}

The videos of the thrombectomy procedures were analyzed after the experiments. The number of passes and the occurrence of distal emboli and emboli in new territories were documented. Distal emboli and emboli in the anterior cerebral artery were counted on the videos.

\section{Results}

Both the red clots and the white clots were successfully produced as described above. $>$ Fig. 1 shows two specimens of the different clots.

Six experiments were conducted per clot model and thrombectomy technique, resulting in a total of $n=24$ experiments.

- Table 1 shows a summary of the results. 
- Fig. 2-4 show the interaction between the techniques and the thrombus in consecutive pictures of live videos. The size of distal emboli and emboli in new territories was max. $3 \mathrm{~mm}$.

\section{Thrombectomy in white clots}

For white clots, BGC and SR showed a lower risk of distal emboli than ADAPT (BGC 1/6, $\mathrm{n}=1$; statistically not significant). Using ADAPT, white clots could not be aspirated entirely ( $\triangleright$ Fig. 2) because the catheter was clogged every time and had to be retracted into the sheath, pulling the clot behind. Thus, the distal part of the clots loosened, causing distal emboli (ADAPT 3/6, $n=6)$.

The stent-thrombus interaction in the BGC group was rather superficial. The thrombus rolled between the retriever and the vessel wall distally, eventually losing the clot shortly before entering the BGC every time. With additional flow arrest, the lost clot could be saved in the petrous ICA and then finally aspirated in the BGC before the balloon was deflated.

There were no emboli in the ACA. In both groups just one pass was necessary for full recanalization.

\section{Thrombectomy in red clots}

For red clots, ADAPT produced fewer distal emboli than BGC. The aspiration catheter was able to retrieve the clot just at the occlusion site without becoming clogged in 4 of 6 cases ( $\nabla$ Fig. 3 ). As soon as the clogged aspiration catheter had to be retracted, distal emboli developed (ADAPT 2/6, $\mathrm{n}=2$; not statistically significant).

The rolling clot phenomenon occurred with red clots as it did in white clots also when using the BGC ( $\triangleright$ Fig. 4). The red clot was more fragile than the white clot, which caused clot fragmentation by the stent retriever in a more distal location (already in the M1 segment or the carotid T). Due to the distal location of the fragmentation, those fragments could not be caught by aspiration via the BGC and caused distal emboli (BGC 4/6, $n=5$ ).

In both groups emboli developed in the ACA ( $1 / 6$, respectively). A maximum of two passes was necessary in both techniques, thus showing no relevant differences.

\section{Discussion}

In this in vitro study, a difference in the effectiveness of thrombectomy could be found depending on the clot composition. RBC-rich thrombi were removed more effectively by ADAPT, and fibrin-rich thrombi by SR/BGC.

Constant physiological vessel architecture, hemodynamics, and thrombus composition were considered important factors to achieve realistic results. However, the lack of endothelium, coagulation factors, and blood cells apart from the thrombus represent limitations in this study. We deliberately selected a transparent vessel and blood model to visualize the thrombectomy procedure throughout all stages. We chose to film the experiments and analyze the direct interaction between the thrombus and the given technique. Chueh et al. published a similar study in 2016 [17], but performed the experiments under fluoroscopic control. However, like in a clinical setting under fluoroscopy, what is happening mechanically during the thrombectomy maneuver is not visible. Liebeskind et al. [14] described that retrieved clots mainly consisted of fibrin and red blood cells (RBC). They categorized thrombi as fibrin-dominant ("white") and RBC-dominant ("red"). Nevertheless, the clots were highly heterogeneous even within those groups, with smooth transitions from one to the other. In this study, we chose representative fibrin-rich and RBC-rich clots made of human blood. Artificial additives such as barium were not used to keep the thrombus as natural as possible, in contrast to other studies $[10,17]$. We are aware that not all possible clot compositions were investigated in our experimental study. However, using more extreme clot compositions, we expected to find differences in the effectiveness of the given thrombectomy techniques. Beyond that, there is a major issue concerning clot composition. The composition of acute clots in ischemic stroke remains unclear because existing histopathological analyses have mostly dealt with retrieved, processed clots. Indeed, it is only possible to approximately determine the actual composition.

Using machine aspiration, a continuous vacuum could be maintained throughout the whole procedure. Chueh et al. used a 20-ml syringe, which makes changing or emptying of the syringe necessary and a loss of vacuum possible and probable [17]. The ADAPT technique can hardly be applied without a good vacuum. In contrast, the stent retriever technique is probably more robust with respect to less effective aspiration.

A higher rate of distal emboli was considered negative in this study. The actual biological effect of those emboli cannot be simulated in a flow model. Nor is it clear how to interpret the size of distal emboli, e. g., very small emboli $(<100 \mu \mathrm{m})$ might be harmful because the occluded microcirculation probably has no collaterals, or harmless because they are more prone to react to medical or intrinsic lysis. Finally, it is not possible to predict whether a certain embolus will produce an infarction, which depends on the collateral flow. Nevertheless, a reduction in the number of emboli is very likely to reduce the probability of infarctions.

The results of our in vitro study are in line with other recently published clinical thrombectomy studies. Brinjikji et al. [18] suggested that BGC use during mechanical thrombectomy for acute ischemic stroke is associated with superior clinical and angiographic outcomes. Teleb [19] concluded that the use of BGC was associated with a good first-pass effect and an overall recanalization of $\mathrm{TICl} 2 \mathrm{~b} / 3$ of $94 \%$. Maegerlein et al. [20] and Turk et al. [21] concluded that ADAPT is a very successful approach to revascularization and shows advantages in comparison to the SR with respect to procedure time and safety, at a similar clinical outcome. In the PROMISE study [22], the ACE68 / ACE64 catheters for aspiration thrombectomy were found to be safe and showed similar efficacy to randomized trials using other revascularization techniques.

The ASTER study [13] showed very similar results with respect to both recanalization rate and clinical outcome comparing ADAPT and SR combined with BGC. Since a randomized patient population was treated and thus an average clot was retrieved, those results do not contradict the findings in our study. Overall both techniques performed well in the flow model and in the clinical setting. 

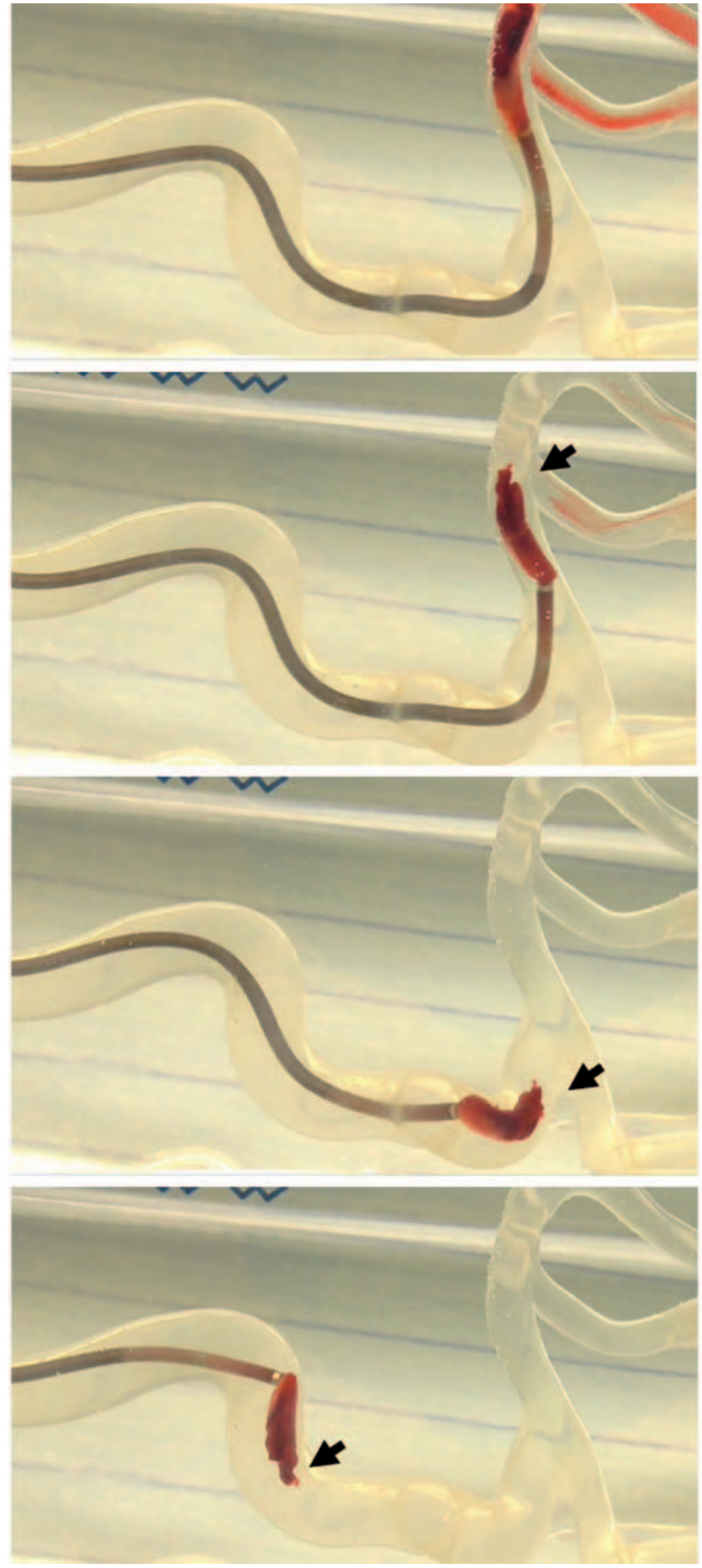

- Fig. 2 Direct aspiration in white clot. The $5 \mathrm{~F}$ aspiration catheter is not capable of aspirating the whole clot. The proximal part of the clot is stuck at the tip of the aspiration catheter. The catheter has to be retracted, while the major part of the thrombus is unprotected (black arrow).

- Abb. 2 Direkte Aspiration bei weißem Thrombus. Der 5F-Aspirationskatheter ist nicht in der Lage, den gesamten Thrombus einzusaugen. Der proximale Anteil des Thrombus verstopft die Spitze des Aspirationskatheters. Der Katheter muss so zurückgezogen werden, während der Großteil des Thrombus ungeschützt ist (schwarzer Pfeil).
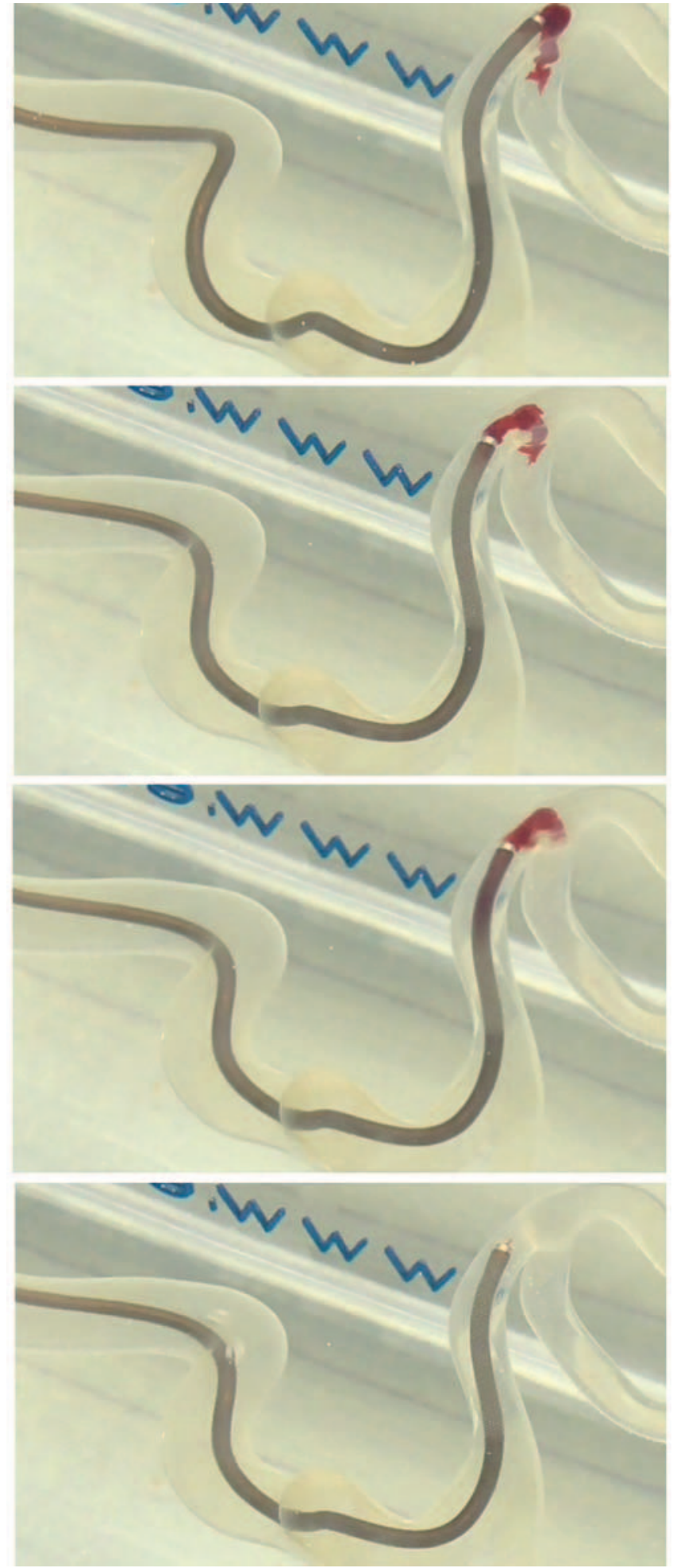

- Fig. 3 Direct aspiration in red clot. The thrombus is aspirated directly at the occlusion site, no clogging of the aspiration catheter.

- Abb. 3 Direkte Aspiration bei rotem Thrombus. Der Thrombus wird direkt an der Okklusionsstelle aspiriert, kein Verstopfen des Aspirationskatheters. 

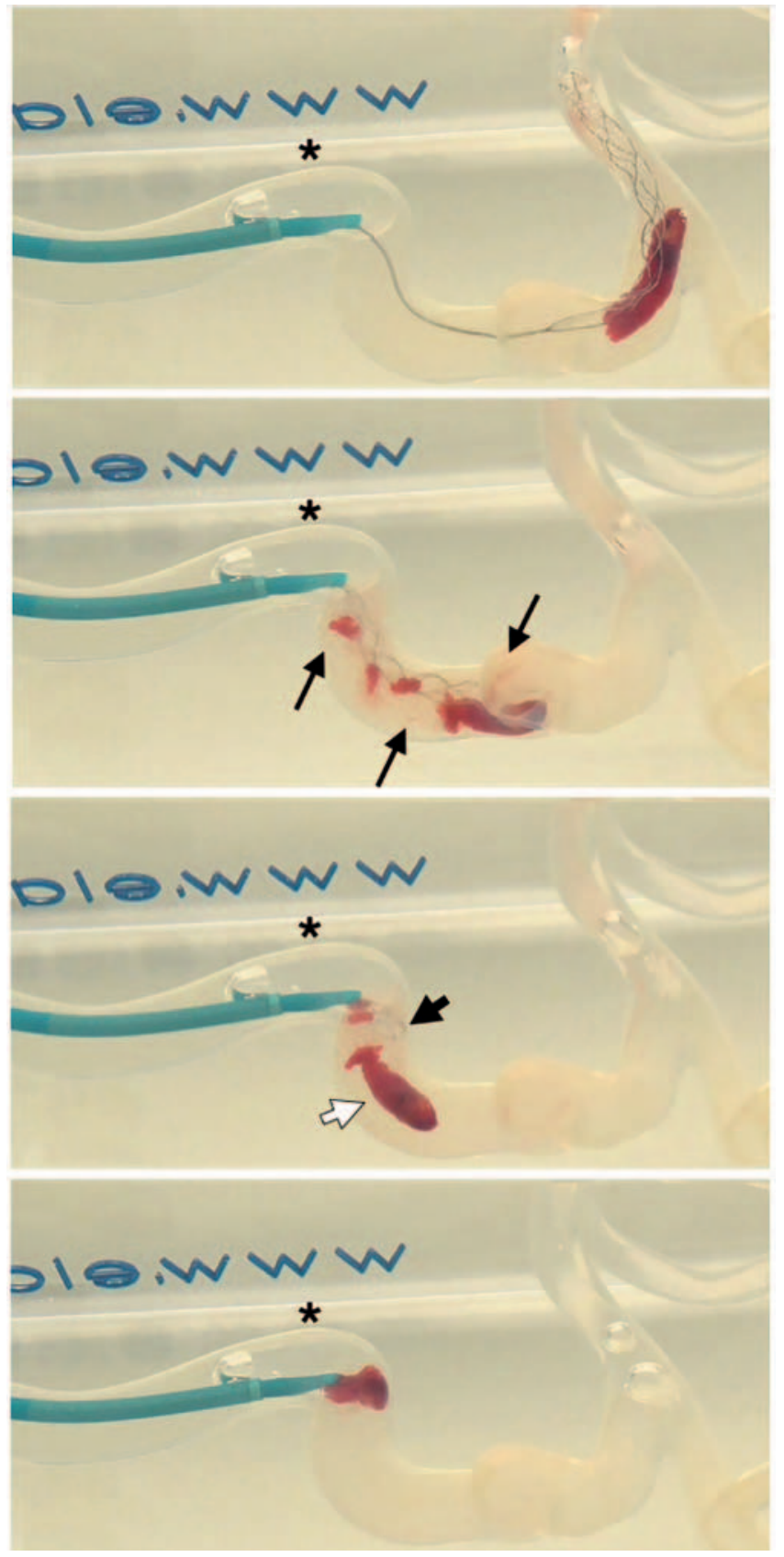

- Fig. 4 Stent retriever with Balloon Guide Catheter in red thrombus. During retraction of the stent retriever, the clot rolls towards the retriever tip and is fragmented (thin black arrows). When the retriever is pulled back into the BGC, a large part of the clot (white thick arrow) loses contact with the retriever tip (black thick arrow). Due to flow arrest and flow reversal in the ICA, this part of the clot is aspirated into the BGC. $\left({ }^{*}\right)=$ inflated balloon.

- Abb. 4 Stent-Retriever mit Ballon-Führungskatheter bei rotem Thrombus. Während des Zurückziehens des Retrievers rollt der Thrombus nach distal entlang des Retrievers und wird fragmentiert (dünne schwarze Pfeile). Als der Retriever in den Ballon-Führungskatheter zurückgezogen wird, löst sich ein großes Fragment des Thrombus vom Retriever (dicker weißer Pfeil). Aufgrund des Flussarrestes und der Flussumkehr in der $\mathrm{ACl}$ wird das Fragment durch den Ballon-Führungskatheter aspiriert. $\left({ }^{*}\right)$ = inflatierter Ballon.
In this study the occurrence of distal emboli using ADAPT depended strictly on whether the aspiration catheter was clogged. If the catheter was clogged, the distal part of the clot was pulled back into the guide catheter in the ICA with no protection and parts of the thrombus were more likely to be lost. In a clinical setting, the clogging can be easily recognized, checking whether there is any backflow during the aspiration, and the results (occurrence of distal emboli) could be checked by post-treatment MRI.

An important observation in the SR+BGC group was that the clot always rolled between the SR and the vessel wall. The longer the distance over which the thrombus had to be retracted, the more the clot moved towards the tip of the SR and was eventually lost in many cases. These findings were already described in two previous independent studies by Madjidyar et al. [6] and Machi et al. [23]. To prevent distal embolization and to increase the number of successful first-pass recanalizations, an advanced thrombectomy technique with proximal flow arrest or an additional aspiration seems to be crucial.

\section{Conclusion}

Although many physiological aspects were incorporated in the model, the experiments were still performed in an artificial environment. This limitation must be considered when interpreting our results. Nevertheless, this study sheds some light on the blind side of mechanical thrombectomy, especially on device-thrombus interaction. Knowing what happens between pre- and postintervention angiograms might reveal how thrombectomy could be taken to a higher level. The selection of the device and technique might depend on the thrombus composition. Thus, preinterventional clot imaging and categorization could become a key for choosing the right recanalization technique. For the moment the clot attenuation on non-enhanced CT (NECT) is promising. There is a link between the density of the clot and the histological composition $[24,25]$. Since almost every patient undergoes NECT, the workflow would not be significantly affected and no delay of therapy would occur. Aspiration catheters or balloon guide catheters with larger lumina might increase the effectiveness.

\section{Conflict of Interest}

The authors declare that they have no conflict of interest.

\section{References}

[1] Berkhemer OA, Fransen PS, Beumer D et al. A randomized trial of intraarterial treatment for acute ischemic stroke. N Engl J Med 2015; 372: 11-20

[2] Saver JL, Goyal M, Bonafe A et al. Stent-retriever thrombectomy after intravenous t-PA vs. t-PA alone in stroke. N Engl J Med 2015; 372: 22852295

[3] Goyal M, Demchuk AM, Menon BK et al. Randomized assessment of rapid endovascular treatment of ischemic stroke. N Engl J Med 2015; 372: 1019-1030

[4] Jovin TG, Chamorro A, Cobo E et al. Thrombectomy within 8 hours after symptom onset in ischemic stroke. N Engl J Med 2015; 372: 2296-2306 
[5] Campbell BC, Mitchell PJ, Kleinig T] et al. Endovascular therapy for ischemic stroke with perfusion-imaging selection. N Engl J Med 2015; 372: 1009-1018

[6] Madjidyar J, Hermes ], Freitag-Wolf S et al. Stent-thrombus interaction and the influence of aspiration on mechanical thrombectomy: evaluation of different stent retrievers in a circulation model. Neuroradiology 2015; 57: 791-797

[7] Nogueira RG, Lutsep HL, Gupta R et al. Trevo versus Merci retrievers for thrombectomy revascularisation of large vessel occlusions in acute ischaemic stroke (TREVO 2): a randomised trial. Lancet 2012; 380: $1231-1240$

[8] Humphries W, Hoit D, Doss VT et al. Distal aspiration with retrievable stent assisted thrombectomy for the treatment of acute ischemic stroke. J Neurointerv Surg 2015; 7: 90-94

[9] Nguyen TN, Malisch T, Castonguay A et al. Balloon guide catheter improves recanalisation, procedure time, and clinical outcomes with Solitaire in acute stroke: analysis of the NASA Registry. J Neurointerv Surg 2013; 5: A2-A3

[10] Chueh JY, Kühn AL, Puri AS et al. Reduction in distal emboli with proximal flow control during mechanical thrombectomy: a quantitative in vitro study. Stroke 2013; 44: 1396-1401

[11] Stampfl S, Kabbasch C, Müller M et al. Initial experience with a new distal intermediate and aspiration catheter in the treatment of acute ischemic stroke: clinical safety and efficacy. J Neurointerv Surg 2016; 8: 714-718

[12] Turk AS, Frei D, Fiorella D et al. ADAPT FAST study: a direct aspiration first pass technique for acute stroke thrombectomy. J Neurointerv Surg 2014; 6: 260-264

[13] Lapergue B, Blanc R, Gory B et al. Effect of Endovascular Contact Aspiration vs Stent Retriever on Revascularization in Patients With Acute Ischemic Stroke and Large Vessel Occlusion: The ASTER Randomized Clinical Trial. JAMA 2017; 318: 443-452

[14] Liebeskind DS, Sanossian N, Yong WH et al. CT and MRI early vessel signs reflect clot composition in acute stroke. Stroke 2011; 42: 1237-1243
[15] Chandler AB. In vitro thrombotic coagulation of the blood; a method for producing a thrombus. Lab Invest 2014; 7: 110-114

[16] Duffy S, Farrell M, McArdle K et al. Novel methodology to replicate clot analogs with diverse composition in acute ischemic stroke. J Neurointerv Surg 2017; 9: 486-491

[17] Chueh JY, Puri AS, Wakhloo AK et al. Risk of distal embolization with stent retriever thrombectomy and ADAPT. J Neurointerv Surg 2016; 8: 197-202

[18] Brinjikji W, Starke RM, Murad MH et al. Impact of balloon guide catheter on technical and clinical outcomes: a systematic review and meta-analysis. J Neurointerv Surg 2018; 10: 335-339

[19] Teleb MS. Endovascular Acute Ischemic Stroke Treatment with FlowGate Balloon Guide Catheter: A Single-Center Observational Study of FlowGate Balloon Guide Catheter Use. Interv Neurol 2018; 7: 327-333

[20] Maegerlein C, Prothmann S, Lucia KE et al. Intraprocedural Thrombus Fragmentation During Interventional Stroke Treatment: A Comparison of Direct Thrombus Aspiration and Stent Retriever Thrombectomy. Cardiovasc Intervent Radiol 2017; 40: 987-993

[21] Turk AS, Turner R, Spiotta A et al. Comparison of endovascular treatment approaches for acute ischemic stroke: cost effectiveness, technical success, and clinical outcomes. J Neurointerv Surg 2015; 7: 666-670

[22] Schramm P, Navia P, Papa R et al. ADAPT technique with ACE68 and ACE64 reperfusion catheters in ischemic stroke treatment: results from the PROMISE study. J Neurointerv Surg 2019; 11: 226-231

[23] Machi P, Jourdan F, Ambard D et al. Experimental evaluation of stent retrievers' mechanical properties and effectiveness. J Neurointerv Surg 2017; 9: 257-263

[24] Sporns PB, Hanning U, Schwindt W et al. Ischemic Stroke: Histologica Thrombus Composition and Pre-Interventional CT Attenuation Are Associated with Intervention Time and Rate of Secondary Embolism. Cerebrovasc Dis 2017; 44: 344-350

[25] Borggrefe ], Kottlors ], Mirza M et al. Differentiation of Clot Composition Using Conventional and Dual-Energy Computed Tomography. Clin Neuroradiol 2018; 8: 515-522 